\title{
CAPITAL ADEQUACY OF COMMERCIAL BANKS IN BULGARIA: IMPACT STRATEGIES
}

\author{
Radka Andasarova*
}

Received: 13. 9. 2016

Case study

Accepted: 5. 12. 2018

UDC 336.71:005.21

DOI https://doi.org/10.30924/mjcmi/2018.23.2.175

\begin{abstract}
The subject of this research in broader terms involves the activities of credit institutions, the prudential requirements and their relation and dependence on the accounting methodology in banks. The broader subject of research serves as a basis for transition to more specific exploration regarding the subject of research the capital and capital adequacy of banks. The major aim of this paper is to reveal strategies that the banks have been using since the beginning of the latest financial crisis to achieve higher capital adequacy levels. An empirical research of the capital components and capital adequacy dynamics
\end{abstract}

\section{INTRODUCTION}

Since the beginning of the last financial crisis, banks in Europe, and in particular in Bulgaria, have been striving to achieve better financial results in the conditions of a constantly changing environment. In fact, the global banking sector has been facing a number of problems since the beginning of 2008. Numerous initiatives have been taken by banks in order to improve the efficiency of their capital and achieve higher levels of capital adequacy, stimulated by high regulatory requirements. of the banking system in Bulgaria over the period 2007-2016 has been conducted to see the actual reflection of the latest capital framework on the capital adequacy of the banking system, and, based on research results, to make conclusions about the existing internal policies and accounting practices that would have an effect on improving the equity of commercial banks and the banking system as a whole.

Keywords: banks, capital adequacy, accounting standards, credit losses, retained earnings, risk-based approach for credit risk

The analysis of capital adequacy of banks is a constant subject of scientific and practical research, given its importance to the financial stability of individual banks, the banking system, and the economy as a whole. Capital adequacy is an indication of the extent to which the equity of a bank is sufficient to absorb the dynamics in the bank's risk profile. Reducing capital adequacy below the minimum level raises doubts about the quality of the loan portfolio and the possible resulting impairment losses. Studied issues are particularly relevant for the banking industry and are

\footnotetext{
*Radka Andasarova, Chief Assist. Dr., Finance and Accountancy Faculty, Accountancy and Analysis Department, University of National and World Economy, Office 1053, "8 dekemvri" Str, 1700 Sofia, Bulgaria, phone: +359 898640584, e-mail: radka_bl@abv.bg
} 
conditioned by the following circumstances; first, the last financial and economic crisis and the need to deepen and improve the analysis and supervision of capital adequacy of banks to ensure financial stability of the banking system, and second, the introduction of Basel III through Capital Requirements Directive (Directive 2013/36/ EU) which was adopted in June 2013 by the $\mathrm{EU}$, and Capital Requirements Regulation (Regulation 575/2013) based on the Directive.

\section{LITERATURE REVIEW}

In theory, there are two main concepts of capital that define its essence as a selfgrowing value, i.e. the financial one (based on the theory of the fund) and the physical concept (based on the school of materialists). They are included in the "Conceptual Framework for Financial Reporting" of the IFRS. The concepts of capital maintenance underline its fundamental importance for the financial stability of enterprises. The financial concept considers capital as funds invested or monetary expression of the value of assets invested in the enterprise. According to it, capital is synonymous with the net assets and profit is realized in case of excessing the amount of net assets at the end of the period in comparison to their size at the beginning of the period. According to the physical concept, profit is expressed in excess of production at the end of the reporting period compared to its beginning and is seen as an increase in resources required to achieve production capacity (IFRS, 2012).

Generally, studies are dedicated to the influence of Basel requirements upon economics in general and upon financial stability of banks. Important factors influencing capital adequacy management are regulation and supervision. For example, Steven (2009) asserts that inadequate bank capital was one of the reasons for global financial crisis . Davis (2010) notes the number of deficiencies in the capital adequacy regime, revealed by the global financial crisis. Vauhkonen (2012) argues that the current financial crisis brings into focus the need for greater transparency and market discipline.

Much research in financial reporting has been concerned with the relationship between capital standards, risk-taking, and accounting rules. Li (2017), for example, analyses how different accounting regimes affect banks' risk-taking decisions through capital regulation, and finds that a lowerof-cost-or-market regime is more effective in controlling banks' risk-taking than other regimes. Bertomeu and Magee (2011) show that a shift of accounting information quality driven by an economic downturn may result in more bad loans. Corona et al. (2015) examine the role of accounting information quality in a product market setting and we focus on the effect of accounting information on banks' risk-taking activities. Besanko and Kanatas (1996) show that when banks resort to issuing new equity in order to satisfy the capital requirement, a more stringent capital requirement may actually lead to more bank failures. On the other hand, Berger (1995) and Banker (2010) consider that stricter capital requirements can improve a bank's capability to address losses, bear risks, and run robust operations. Latvian economist Kudinska (2016) determines factors influencing bank's own capital adequacy and assessment of financial strength of the capital of commercial banks.

Dobrev (1946) defines capital as a "collective expression of all means that the business operator owns and which are intended for the acquisition of business targets". 
Studies on capital as the subject of accounting can be found in the works of Dushanov (2008), Dinev (2012), Stoyanov (2010), and Basheva (2013). A modern definition of capital as an object of accounting is related to its incarnation as a monetary expression of the value of assets invested in an enterprise or a bank. The amount of equity is defined as the difference between the value of assets and liabilities of a single economic unit. Therefore, capital is cumulative monetary expression of the funds that are invested in a company or bank (Feschiyan, 2005). The capital acts as a buffer that is intended to absorb losses from loans and other current losses, ensuring the protection of depositors. Equity is monetising the possessions of the owners of the property (assets) of an enterprise (Basheva, 2013). While attracted capital is defined as the sum of liabilities (obligations), it is logical to assume that equity has an independent definition - it does not meet the legal definition of liability (foreign capital), as it shows the source of their own (or equivalent) means. Dinev (2013) also noted that "after all, equity also shows the commitment of the enterprise to its shareholders or owners, it is also a responsibility for the preservation of this source".

Russian economist Kopytova (2009) interprets capital adequacy as a factor reflecting the bank's overall stability and connects the concept to bank's potential risks, with a comment that the greater the specific weight of risk-generating assets on a bank's balance sheet is, the greater the bank's capital should be.

There is no specific definition of equity in the legislation. It is defined as the residual interest in the assets of an enterprise after deducting all of its liabilities in the conceptual framework for financial reporting to IFRS. The methods of formation, maintenance and increasing the equity determine its composition and structural elements. The structure of the equity is not strictly defined in the International Accounting Standards (IAS). According to the IAS 1 Presentation of Financial Statements, equity consists of share capital, reserves, financial result, retained earnings, and uncovered losses from previous years. The composition of equity, but with a negative sign, also includes own shares bought.

After the Bulgarian accession to the EU in 2007, the legislation underwent significant changes in order to comply with EU directives in the field of company law, the IAS Regulation (No. 1606/2002 and No. 1126/2008) and the Directive on the Annual Accounts and Consolidated Accounts of Banks and Other Financial Institutions (86/635/EEC, 1986).

The statutory regulation of capital is extremely complicated. In the Bulgarian banking system, it is subject to the legislative framework for the implementation of the last Capital Accord - Basel III in the European Union by introducing the CRR/CRD IV package. The package contains the Capital Requirements Regulation (Regulation (EU) No. 575/2013) - directly applicable to the Member States and the Fourth Capital Requirements Directive (Directive 2013/36/EU), transposed into national law by the Law on Credit Institutions (LCI) and the acts on its application. Equity is an indicator of the bank's own funds and is formed by the sum of Tier 1 capital and Tier 2 capital.

Since the beginning of 2003, banks in Bulgaria have been preparing and presenting their financial statements based on the International Financial Reporting Standards adopted by the European Commission. Although the national regulatory authority in the face of BNB and the National Revenue Agency (NRA) adopted the 
endorsed IFRS as the basis for financial reporting, it is important to note that credit institutions in Bulgaria should prepare and present their financial statements according to the instructions of the Bulgarian National Bank (BNB), referred to as the supervisory financial statements.

In order to bring Bulgarian legislation in line with the new EU legal framework for the activities of credit institutions, BNB introduced a new accounting framework for reporting supervisory financial information, including the financial reporting framework for the IFRS (FINREP), the framework for reporting on equity and capital requirements (COREP), and other supervisory financial information necessary for a comprehensive view of the risk profile of the institution and the notion of systemic risks.

The framework for financial reporting under the IFRS (FINREP) and the framework for reporting on equity and capital requirements (COREP) regulate the following main components of equity (Table 1 ):

Table 1. Structure of equity under the framework for financial reporting under IFRS (FINREP) and the framework for reporting on equity and capital requirements (COREP)

\begin{tabular}{|c|c|}
\hline $\begin{array}{c}\text { BALANCE SHEET } \\
\text { (STATEMENT OF FINANCIAL POSITION) } \\
\text { EQUITY } \\
\text { Framework for financial reporting under the } \\
\text { IFRS (FINREP) }\end{array}$ & $\begin{array}{l}\text { Framework for reporting on equity and capital requirements } \\
\text { (COREP) }\end{array}$ \\
\hline COMPONENTS OF EQUITY & COMPONENTS OF EQUITY \\
\hline 1.1 Capital & 1.1 TIER 1 CAPITAL \\
\hline 1.2 Premium reserves & 1.1.1 TIER 1 BASIC EQUITY \\
\hline $\begin{array}{l}\text { 1.3 Capital instruments issued, other than } \\
\text { capital }\end{array}$ & 1.1.0.1 Capital instruments eligible as Tier 1 basic equity \\
\hline 1.4 Other equity & $\begin{array}{l}\text { 1.1.0.2 } \\
\text { Retained earnings: } \\
\text { (Retained earnings from previous years } \\
\text { Reasonable profit or loss } \\
\text { Profit or loss that relates to the owners of parent } \\
\text { company } \\
\text { (-) Unacceptable part of interim or annual profit) }\end{array}$ \\
\hline 1.5 Other comprehensive income accumulated & 1.1.0.3 Other comprehensive income accumulated \\
\hline 1.6 Retained earnings & 1.1.1.4 Other reserves \\
\hline 1.7 Revaluation reserves & 1.1.2 ADDITIONAL TIER 1 CAPITAL \\
\hline 1.8 Other reserves & $\begin{array}{l}\text { 1.1.2.1 Capital instruments eligible as additional Tier } 1 \\
\text { capital }\end{array}$ \\
\hline $1.9(-) \quad$ Treasury shares & 1.2 TIER 2 CAPITAL \\
\hline $\begin{array}{l}\text { 1.10 Profit or loss that relates to the } \\
\text { owners of a parent company }\end{array}$ & $\begin{array}{l}\text { 1.2.1 Capital instruments and subordinated loans eligible } \\
\text { as Tier } 2 \text { capital }\end{array}$ \\
\hline \multicolumn{2}{|l|}{1.11 (-) Interim dividends } \\
\hline $\begin{array}{l}1.12 \text { Minority interests } \\
\text { [Non-controlling interests] }\end{array}$ & \\
\hline
\end{tabular}

Source: $B N B$ 
It is difficult to accurately determine the amount of capital required by banks. It is subject to the influence of many factors with different manifestation in particular economic conditions. At the same time, defining the required amount of equity of each bank is a task of a paramount importance.

\section{IMPACT STRATEGIES TO IMPROVE THE CAPITAL POSITION OF THE BANKING SYSTEM - EMPIRICAL RESEARCH}

A case study on the components and dynamics of capital and the levels of capital adequacy of the banking system in Bulgaria has been carried out and conclusions about the existing internal policies and accounting practices that have an influence on improving capital positions of the banking system as a whole have been made based on the results. The study covers the period 2007-2015 as it seeks to analyse the effects of the last global financial and economic crisis of the banking system on the one hand, and on the other hand, to follow the preparation of credit institutions in Bulgaria for the last global financial reform programme - Basel III.

From the beginning of 2007 until March 2014, in the Bulgarian legal framework the minimum levels of capital adequacy ratios stood at $12 \%$ for total capital adequacy and $6 \%$ for Tier 1 capital adequacy compared with those set out in Basel II - 8\% and 4\% respectively. Regarding the requirements of the last Basel Accord (Basel III), the minimum requirements for basic primary and primary capital are: increase in basic Tier 1 equity to $4.5 \%$ and Tier 1 capital to $6 \%$. Apart from that, the banks in Bulgaria should maintain a safety capital buffer of basic Tier 1 equity equal to $2.5 \%$, capital buffer for systemic risk in the amount of 3\% of risk-weighted exposures and zero countercyclical capital buffer (until mid-2016). Banks in the country have strong capital positions. They remain at a level of above $16 \%$ at the end of 2013 and above $22 \%$ at the end of 2016, which are significantly higher levels as compared to international ones and also compared to the minimum domestic capital requirements (Figure 1).

Figure 1. Graphical representation of the dynamics of capital adequacy of banks in Bulgaria as of December 31 for the period 2007-2016

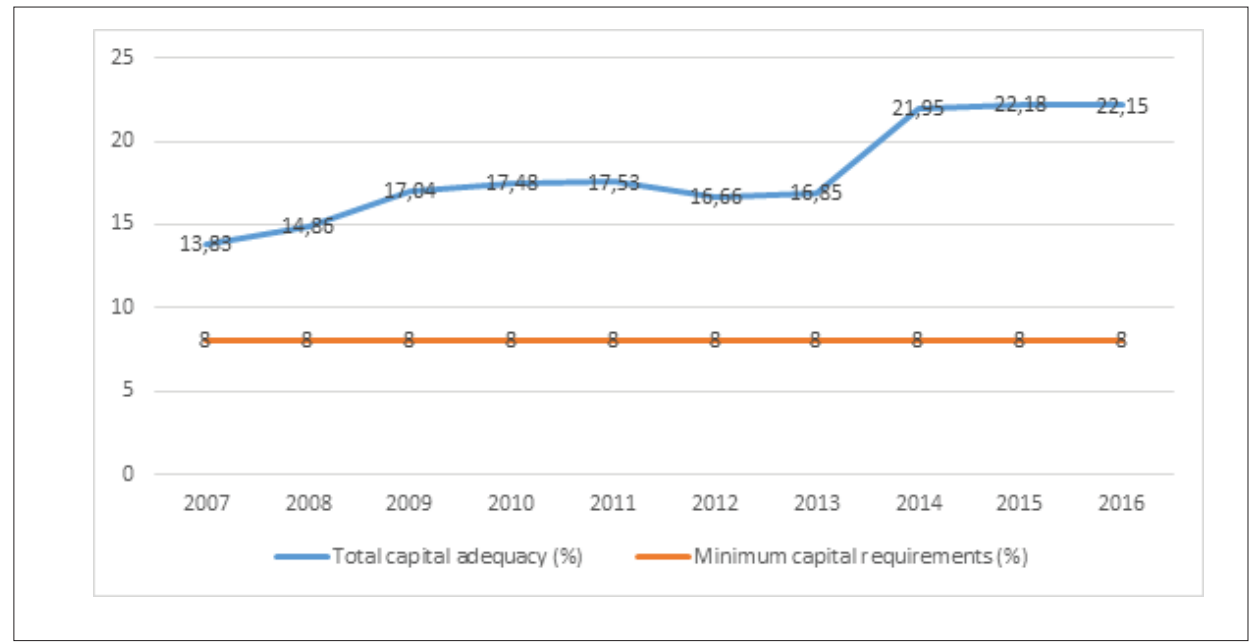

Source: $B N B$ 
High levels of capital adequacy in the country (over 20\%) in the last two years of the review period are a result of eliminating the so-called specific provisions for credit risk, which represented a specific feature of the supervisory regime in Bulgaria, which contributed to the accumulation and preservation of capital buffers against losses from future events; the provisions were a part of the calculation of capital adequacy. Pursuant to the requirements of the Ordinance No. 9 of BNB cancelled in April 2014, banks in Bulgaria formed the so-called specific provisions for credit risk. They represented the excess of the carrying amount calculated under the applicable accounting standard over the risk value of exposure. Under this enactment, the specific provisions for credit risk were established against particular exposures classified as under surveillance, non-performing or loss. A characteristic feature of specific provisions for credit risk is that they were not subject to accounting but were deducted directly from the bank's equity.

We could conventionally group different strategies that commercial banks in Bulgaria have been using to achieve higher levels of capital adequacy since the beginning of the last financial crisis as follows:

A) Recognition of impairment for credit losses within the meaning of the applicable accounting standards.

A major methodological moment when trying to properly understand the issue of impaired loans due to uncollectibility and deteriorated financial condition of the debtor is its treatment under the terms of International Financial Reporting Standards (IFRS/IAS). Banks in the EU are on the verge of introducing a new standard - IFRS 9 Financial Instruments which changes the accounting organization and methodology for reflecting financial assets and in particular the recognition of impairments (provisions) for credit risk. A fundamental change in the newly adopted accounting standard is the concept of recognizing and measuring expected credit losses, implying new principles and modelling techniques in the context of the accounting rules for credit risk impairment. The process of final approval of the IFRS 9 Financial Instruments ended in the last quarter of 2016. The standard was adopted by the European Commission with Regulation 2016/2067 of November 22, 2016 and published in the Official Journal, L 323 of November 29, 2016; this act upheld the decision for the mandatory application of the standard for all EU member states for accounting periods beginning on or after January 1, 2018 and will succeed the current IAS 39 Financial Instruments: Recognition and Measurement.

When servicing the loan, at each reporting date (the date the financial statements are prepared, necessarily at the end of the year) banks assess whether there is objective evidence of impairment of a financial asset or a group of financial assets in accordance with the provisions of the Standard. Under the provisions of the $I F R / I A S$, the impairment defined is subject to accounting, recognized in profit or loss (treated as an expense). Increasing the amount of impairments is reflected in the income statement, resulting in a decrease in net income and reflecting the capital positions of commercial banks (reduction of equity - Table 1).

The degree of impairment under the applicable accounting standards (IAS 39 Financial Instruments: Recognition and Measurement) of classified exposures for the period 2007-2016 for Bulgaria's banking system is presented in Figure 2.

The results put forward the worrying issue of the sufficiency of bank capital in 
Figure 2. Dynamics of impairments for credit losses of commercial banks in Bulgaria for the period 2007-2016 in thousands BGN

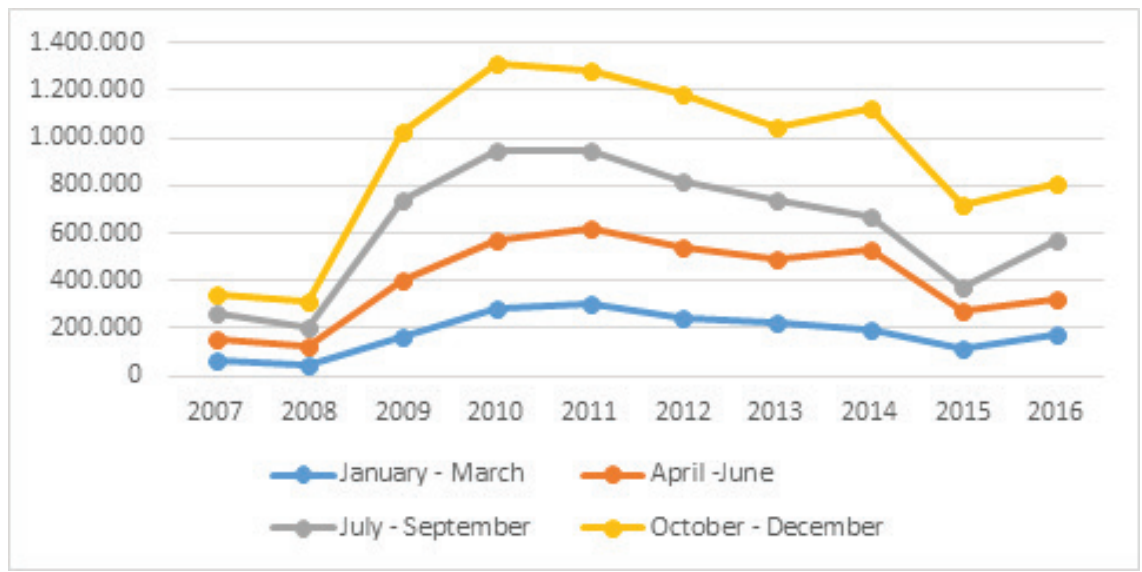

Source: $B N B$

the country and its ability to absorb future losses, especially in the period of a continuous deterioration in the loan portfolio of the Bulgarian banking system.

The impairments charged show very different sub periods - from the beginning of the global financial crisis (2007-2008) with average values just over 161 million BGN; (2009 - 2014) - with the highest values, averaging over 580 million BGN; and in 2015-2016) - with average levels of impairment identical to the beginning of the crisis -382 million BGN.

It is essential to analyse the status and trends of non-performing loans (for the purpose of study, loans with impaired service are considered credit exposures past due over 90 days). Their growth depends less on credit policy and risk management systems at individual banks. Non-performing loans are largely a function of the country's economic activity (real GDP for example) and to a lesser extent of interest rates, as there is an inverse proportion compared to the first variable, and a positive correlation compared to interest rates (Beck et al., 2013).

Generally, non-performing loans have increased several times since the last crisis began. If in 2007-2008 the average change in non-performing loans increased about $35 \%$ for our country, in the following period 2009-2013 it was already over 60\%, and for the last two years of the reviewed period it reached values in the range of $16 \%$ in the direction of reduction (Table 3 ). The decrease could be a result of the sale of bad loans or restructuring of credit debt through remission or deferral of payment of principal and interest.

However, when we track and compare the rate of change in impairments for credit risk with the rate of change in non-performing loans, we can reach a conclusion that the rate of change towards lowering the level of impairment in the last four years of the review period (over 50\% for both halves of 2015) cannot be explained by the same rate of change towards lowering the 
Figure 3. Rate of change in impairments for credit losses and classified risk exposures by quarter for the period 2007-2015 in \%

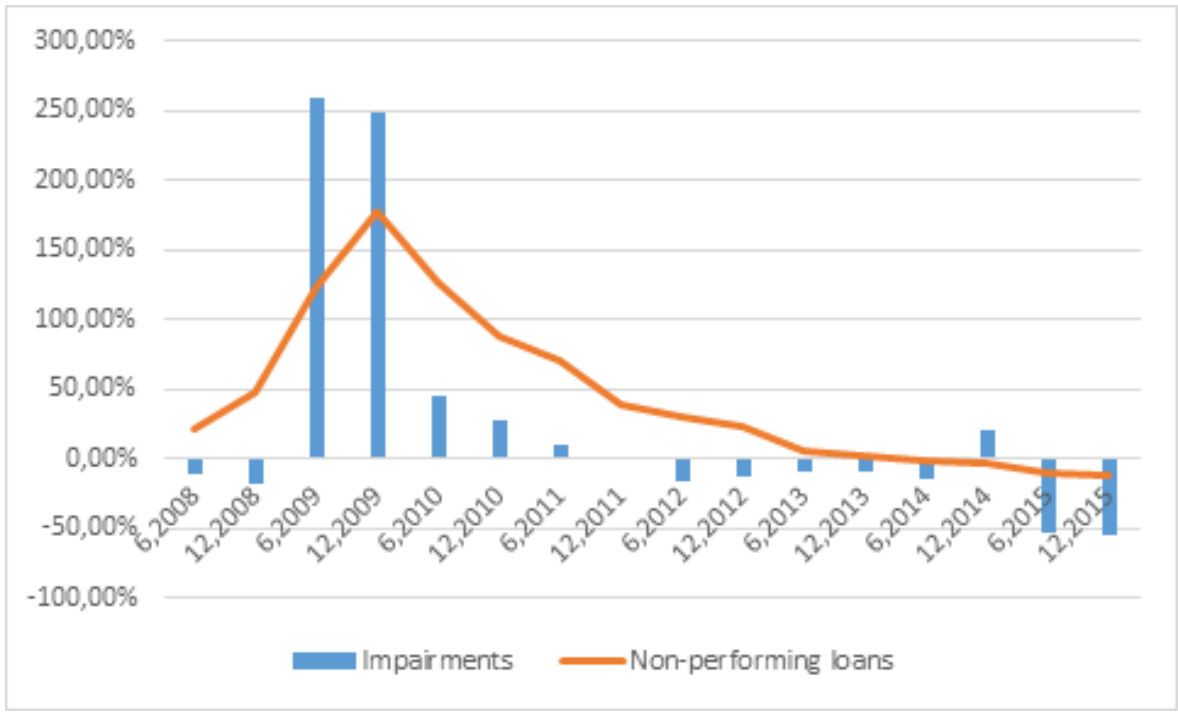

Source: $B N B$

non-performing loans (average of $10 \%$ for 2015) (Figure 3).

The fact that the management of a bank can manage their income through impairments is undisputed. The impairment amount would depend on the experience of the bank's management, on the existing contacts with customers, on the market situation prevailing at the balance sheet date, on the specific environment conditions in which the company operates, on the specific economic conditions in the country on the micro and macro levels, and on major trends in international economic conditions. Researches conducted over the last few years in the field of bank provisioning (impairment) using econometric models generally show that accounting rules relating to impairment (provisioning) influence the activities smoothing the income of commercial banks (El Soo, 2012; Deloitte, 20142015; Ernst \& Young, 2011-2012).
B) Increasing equity by capitalization of profits The essence of financial results as a component of capital is crucial for commercial banks (Table 1). Profit at the end of a period is a sign of financial stability, good capital position and an indicator of the efficient use of resources and sustainable development of a credit institution. Financial results include retained earnings from previous years, uncovered loss from previous years, profits and losses from the current year and the result in the case of company bankruptcy and liquidation (Dushanov \& Dimitrov, 2011).

Retained earnings is a component of equity under the financial reporting framework for IFRS (FINREP), and an element of fixed equity under the framework for reporting on equity and capital requirements (COREP).

Current profit or accumulated profits can be distributed as dividends. Dividend 
policy deals with decisions on the allocation of profits. The option to distribute a portion of the profit as a dividend and to reflect the remainder as retained earnings should not be ignored. The balance between dividends paid to shareholders and reinvested profit is essential for the prosperity and financial stability of a banking institution. Procházka (2011) argues that a possible risk of capital erosion stems from the distribution of unrealized profits. The function of accounting is not to hinder the users from distributing unearned profits. Financial reporting should only inform users what can be distributed without erosion of capital. However, the decision whether to maintain the entity's capital is just up to the owners. The restrictions set by state authorities can be a limiting factor for distribution of profits in order to protect the creditors, minority owners, etc.

The rate of change in retained earnings and current profit are presented graphically in Figure 4 and Figure 5.
As noted above, net profit of commercial banks can be used for different purposes according to the chosen business strategy - dividends can be distributed to increase equity, own shares or reserves can be repurchased, etc. Generally, the analysis shows significant differences in the behaviour of banks during the first years compared to the last two years of the analysed period. For commercial banks in Bulgaria in the period 2015-2016, the most common option was to distribute the net profit as dividends and not to leave it as an unallocated amount. Higher dividend payments and lower levels of retained earnings result in lower capital ratios of commercial banks. However, according to the official data of the Bulgarian National Bank, the Bulgarian banking system had the highest growth in the levels of capital adequacy in the period 2014-2016 (Figure 1). Another group of variables contributed the most to high levels of capital adequacy for the said period. These are specific provisions for credit risk, which by their nature

Figure 4. Rate of retained earnings of CBs in Bulgaria for the period 2007-2016 in thousand BGNs

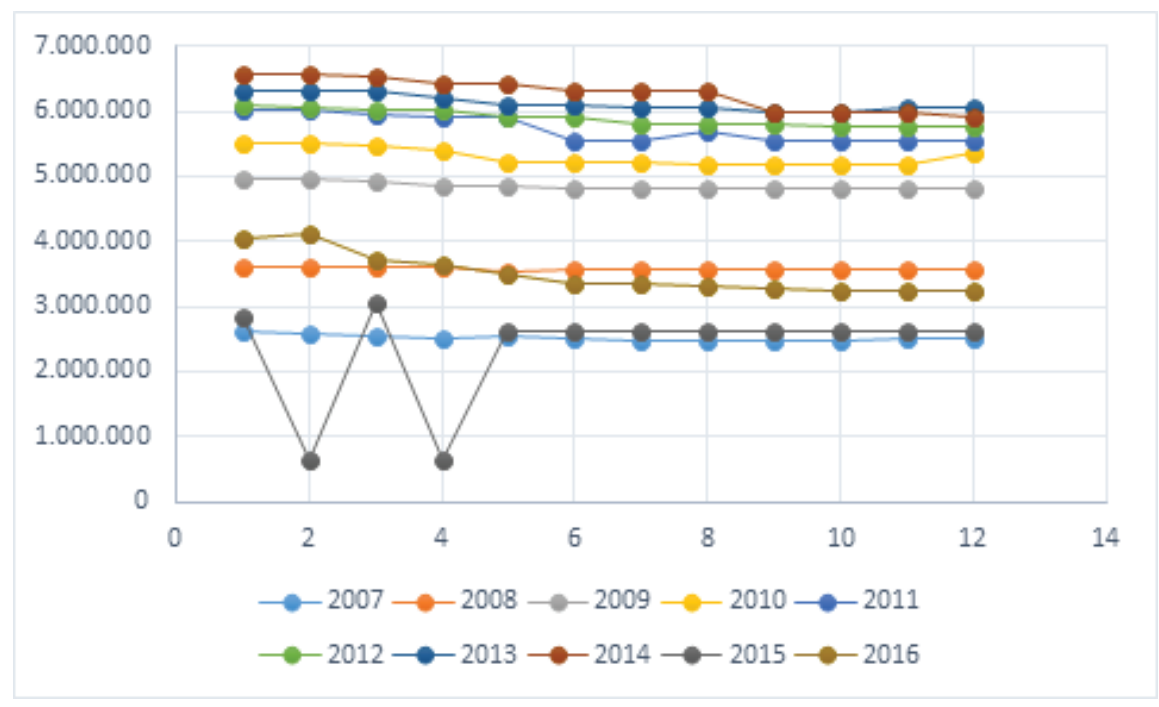




\section{Journal of Contemporary Management Issues}

Figure 5. Rate of current profit for the period 2007-2016 in thousand BGNs

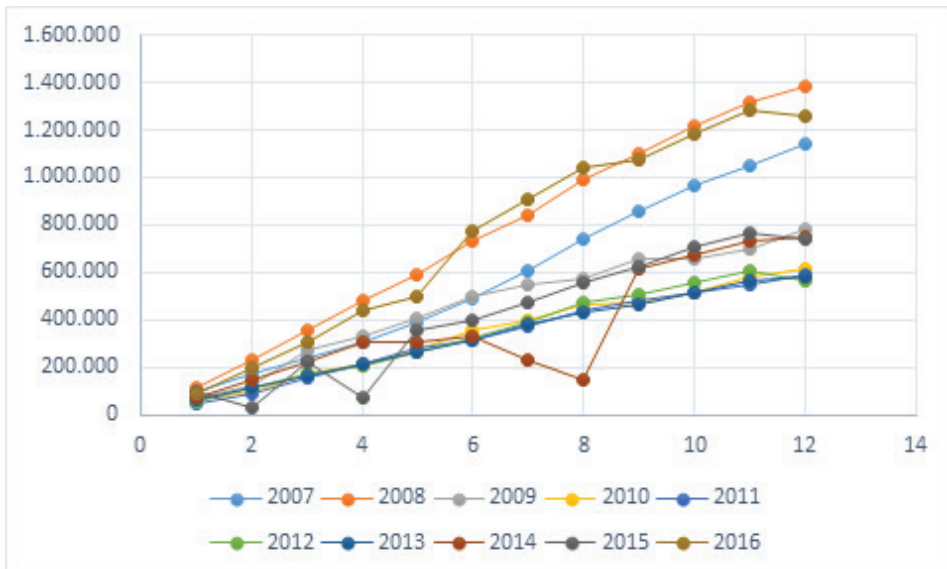

Source: $B N B$

played the role of an additional capital buffer reported as a decrease (rebate) of the equity capital of banks in accordance with the national regulation in force until early 2014.

C) The "capital adequacy - credit risk" relation

Banks must maintain equity capital at all times to meet the overall risk profile of the credit institution. Therefore, an analysis of capital adequacy requires a disclosure of risks taken by the bank and a definition of the components of equity. An increasing economic uncertainty increases the importance of capital adequacy analysis, in particular for the management and reporting of equity, and stresses the need for a better understanding of their nature for a more accurate calculation of risk. Effective methods for a sustainable development of commercial banks are directly related to the maintenance of the capital base (equity) within the changing economic environment and in accordance with the applicable supervisory framework and prudential rules.

It is known that the source for the formation of retained earnings is bank's current profit. In this line of thought, "charging" is the key accounting principle included in the Accounting Act (2016), involving a "recognition of the effects of transactions and other events when they occur, regardless of the time of receipt or payment of cash or its equivalents, and are included in the financial statements for the period to which they relate". In other words, profit is likely to be derived primarily from the increased amount of overdue receivables on loans that have already been accounted for as income (interest income) before cash equivalent has been received. If there is a principle of "charge" there are conditions to create a so-called "hollow profit", i.e. unreal income should not be distributed.

An argument in favour of the "capital adequacy - credit risk" is the perception of the risk-based approach for measuring capital. Banks apply the mechanism to determine the risk-weighted assets for credit risk - they evaluate their customers' solvency by using a credit rating, and depending on the method of determining this credit rating, they apply a standardized (based on external credit ratings) or IRB approach (based on internal credit ratings). In calculating capital requirements, the largest share 
occupy requirements of the credit risk, formed from the assets in the banking portfolio - provided loans and commitments by the bank, investments in securities.

At the end of 2016 all banks in Bulgaria, with the exception of UniCredit Bulbank, started applying the standardized approach for determining risk-weighted assets for credit risk. For this purpose, each exposure shall be assigned to one of the classes in the Capital Requirements Regulation (CRR, №575/2013), then, depending on the class, a risk weight is given. In other words, if an asset is a high-risk one it gets a higher risk weight and will 'load' equity significantly more opposed to a low-risk asset that gets lower risk weight. Assessing risk capital makes it necessary to compare the level of capital to the quality of the bank's assets, which determines the strong sensitivity of capital adequacy to credit risk inherent in banking assets.

\section{CONCLUSION}

The most important conclusion is that for the period 2007-2016 the specific requirement for minimum capital adequacy does not represent a real restriction for commercial banks in Bulgaria. At the end of 2016 banks are well-capitalized with acceptable levels in terms of common equity, both before and during the last financial crisis. Crucial, however, have been the accompanying strategies for achieving higher levels of capital adequacy, and also that by the adopted internal policies and accounting practices one could affect the capital positions of banks, namely:

a) The accounting effect of adjustments on impairments for credit risk under the current IFRS/IAS. An impairment is subject to accounting being recognized in profit or loss (treated as expense). An increase in the amount of impairments is reflected in the income statement, resulting in a decrease in net income and reflecting the capital positions of commercial banks (reduction of equity), and vice versa.

b) Capitalisation of profits to maintain stable capital positions of commercial banks. In the period 2008-2011, banks in Bulgaria reached acceptable levels of equity by reducing dividend payments and accumulation of retained earnings. Opposite is the strategy of banks in the last two years of the review period (2015-2016). High dividend payments do not allow banks to use retained earnings for capital formation. Another group of variables has the greatest contribution to the high levels of capital sufficiency in the past two years. These are the specific provisions for credit risk, which by their nature played the role of an additional capital buffer reported as a decrease (rebate) of the equity capital of banks in accordance with the national regulation in force until early 2014.

c) Applying the risk-based approach for credit risk assessment. The orientation of commercial banks towards low-risk assets will "load" equity significantly less, unlike the high-risk asset that gets a higher risk weight. 


\section{References}

1. Abou-El-Sood, H. (2012). Loan loss provisioning and income smoothing in US banks pre and post the financial crisis. International Review of Financial Analysis, 25, 64-72.

2. Accounting Act (2016). Darjaven Vestnik, 95.

3. Banker R.D., Chang H., \& Lee, S.Y. (2010). Differential impact of Korean banking system reforms on bank productivity. Journal of Banking and Finance, 34(7), 1450-1460.

4. Basheva et al. (2013). Principles of Accounting. Sofia: UPH Economy.

5. Berger, A.N. (1995). The profit-structure relationship in banking-tests of market-power and efficient-structure hypotheses. Journal of Money, Credit and Banking, 27 (2), 404-431.

6. Bertomeu, J., \& Magee, R. (2011). From low-quality reporting to financial crises: Politics of disclosure regulation along the economic cycle. Journal of Accounting and Economics, 52 (2-3), 209-227.

7. Besanko, D., \& Kanatas, G. (1996). The regulation of bank capital: Do capital standards promote bank safety? Journal of Financial Intermediation, 5 (2), 160-183.

8. Beck, R., Jakubik, P., \& Piloiu, A. (2013). Non-performing loans: what matters in addition to the economic cycle. European Central Bank working paper series, 1515, 34.

9. Corona, C., Nan, L., \& Zhang, G., (2015). Accounting Information Quality, Interbank Competition, and Bank Risk-Taking. Accounting Review, 50(3), 967-985.

10. Davis, K. (2010). Bank Capital Adequacy: Where to Now?, working paper, University of Melbourne, 24 May.

11. Deloitte (2015). Fifth Global IFRS Banking Survey Finding your way. Available at: https://www2.deloitte. com/content/dam/Deloitte/global/ Documents/Financial-Services/dttl-fsi5th-IFRS-Bank-Survey.pdf

12. Deloitte (2014). Fourth Global IFRS Banking Survey, Ready to Land. Available at: http://www2.deloitte.com/ content/dam/Deloitte/at/Documents/audit/fourth-global-ifrs-banking-survey. pdf.

13. Dinev, M., \& Zlatareva, K. (2012). General Theory of Accounting, VUZF University, Sofia

14. Dobrev, D. (1946). Systematic Course in Accountancy, Student fund, Sofia, 12-13.

15. Dushanov, I., \& Dimitrov, M. (2011). Course in Company Accounting, Sofia: Romina, 94.

16. Dushanov, I. (2008). General Theory of Accounting, 58,73.

17. Ernst\&Young (2012). The new impairment model. US financial institutions weigh in on the new impairment model being developed by the FASB and IASB Available at: http://www. ey.com/Publication/vwLUAssets/TheIASBs-new-impairment-model/\$FILE/ Impairment-survey-2011.pdf.

18. European Commission (2008). Commission Regulation (EC) No $1126 / 2008$ of 3 November 2008 adopting certain international accounting standards in accordance with Regulation (EC) No 1606/2002 of the European Parliament and of the Council (Text with EEA relevance). Available at https://eurlex.europa.eu/legal-content/EN/ ALL/?uri=celex:32008R1126 
19. European Commission (2013). Regulation (EU) No 575/2013 of the European Parliament and of the Council of 26 June 2013 on prudential requirements for credit institutions and investment firms and amending Regulation (EU) No 648/2012. Available at https://eurlex.europa.eu/legal-content/EN/ TXT/?uri=CELEX\%3A32013R0575

20. Feschiyan, D. (2005). Accounting as a Source of Information for the Management of Capital Adequacy of Banks and the New Basel Capital Accord. Sofia: Economy, 35.

21. IFRS. (2012). Conceptual Framework for Financial Reporting: ICPA.

22. Kopytova, A. I. (2009). Banki i bankovskoe delo: ucheb. posobie. Tomsk: Izd-vo TGPU.

23. Kudinska, M. (2012). Analysis of Bank Capital Adequacy: the Case of Latvia. Journal of Business Management, 6, 123-138.

\section{KAPITALNA ADEKVATNOST KOMERCIJALNIH BANAKA U BUGARSKOJ: STRATEGIJE DJELOVANJA}

\section{Sažetak}

Ovo se istraživanje, $u$ širem smislu, bavi aktivnostima kreditnih institucija, zahtjevima opreznosti i njihovom povezanošću te ovisnošću o metodologiji računovodstva u bankama. Šire tematsko područje rada služi kao osnovica $z a$ analizu specifične problematike kapitala $i$ kapitalne adekvatnosti banaka. Temeljni cilj rada je istražiti strategije, koje banke koriste od početka zadnje financijske krize, kako bi postigle više razine kapitalne adekvatnosti. Provedeno je empirijsko istraživanje komponenti kapitala $i$ dinamike kapitalne adekvatnosti bankovnog
24. Li, J. (2017). Accounting for Banks, Capital Regulation and Risk-Taking. Journal of Banking and Finance, 74,102-121.

25. Procházka, D. (2011): The Role of Fair Value Measurement In The Recent Financial Crunch. Economics, Management, and Financial Markets, 6(1), 989-1001.

26. Steven, Glenn (2009). "Developments in Financial Regulation" Reserve Bank Bulletin, December, 28-34, available at:http://www.rba.gov.au/publications/ bulletin/2009/dec/pdf/bu-1209-4.pdf

27. Stoyanov, S., \& K. Savova. (2010). General Theory of Accounting. Sofia: Economy, p. 21.

28. Vauhkonen, J, (2012). The impact of Pillar 3 disclosure requirements on bank safety. Journal of Financial Services Research, 41 (1-2), 37-49. sustava u Bugarskoj u periodu 2007-2016, kako bi se uočila refleksija novog sustava regulacije kapitala na kapitalnu adekvatnost bankovnog sustava te, na temelju rezultata istraživanja, donijeli zaključci o postojećim internim politikama i računovodstvenim praksama, koje bi mogle imati efekta na unapređenje kapitala komercijalnih banaka $i$ cijelog bankovnog sustava.

Ključne riječi: banke, adekvatnost kapitala, računovodstveni standardi, kreditni gubici, zadržana zarada, pristup riziku kredita 